\title{
Preliminary Studies on Antibacterial and Antiviral Activities of Five Medicinal Plants
}

\author{
Abdel-Shafi $\mathbf{S}^{*}$ \\ Botany and Microbiology Department, Faculty of Science, Zagazig University, Egypt
}

\begin{abstract}
It is of interest to inhibit the pathogenic bacteria and virus by medicinal plants. This method is safe and cheap. The antimicrobial activities of aqueous infusion and decoction of five medicinal plants: Nigella sativa (NS), Zingiber officinale, Thymus vulgaris, Syzygium aromaticum, Mentha piperita were investigated. The screening of antibacterial activity was against Staphylococcus aureus, Pseudomonas aeruginosa, Escherichia coli, Listeria monocytogenes, Lactococcus lactis and Bacillus cereus. The aqueous infusion of ginger exhibited maximum activity against $E$. coli with $15.00 \mathrm{~mm}$ inhibition zone (IZ). Also, the infusion of black seeds showed highest antibacterial activity against Lactococcus lactis, P. aeruginosa, L. monocytogenes, and Staphylococcus aureus with 22.30, 9.60, 9.50 and 9.00

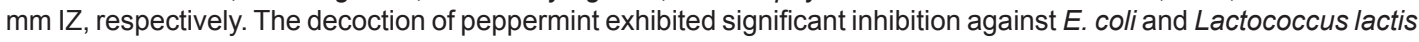
(20 and $19.5 \mathrm{~mm}$, respectively), while decoction of black seeds showed maximum inhibition against $P$. aeruginosa and $B$. cereus with 9.50 and $9.3 \mathrm{~mm}$. The decoction of clove inhibited L. monocytogenes and Staphylococcus aureus significantly compared to other plants. Further antiviral screening was done. The effect of NS extracts as inhibitors against Zucchini yellow mosaic virus (ZYMV) infectivity in-vitro and in-vivo was studied. Aqueous decoction and infusion of NS inhibit the production of ZYMV symptoms on squash plants by $85 \%$ and $80 \%$, respectively, in vitro treatment. Upon using of NS infusion and decoction, the phenolic compounds, the total protein as well as peroxidase and polyphenol oxidases were increased, comparing to viral controls. The infusion and decoction of medicinal plants were effective against tested virus and bacteria.
\end{abstract}

Keywords: Medicinal plants; Pathogenic bacteria; ZYMV

\section{Introduction}

Pathogenic bacteria can invade in the body through inhalation into nose and lungs, ingestion in food or through sexual contact. General symptoms of bacterial diseases include fever, chills, headache, nausea and vomiting. Commonly occurring pathogenic bacteria are Staphylococcus aureus, Pseudomonas aeruginosa, Escherichia coli, Listeria monocytogene [1]. Commonly occurring pathogenic bacteria are Staphylococcus aureus, Pseudomonas aeruginosa, Escherichia coli, Listeria monocytogene.

The use of medicinal plants is very important to our health. All drugs of the past were extracted from medicinal plants [2]. The medicinal plants have been screened for their antimicrobial activities. Medicinal plants were used in traditional medicines to treat infectious diseases. It contains new bioactive secondary metabolites [3]. The phenolic compounds showed antibacterial and antiphytoviral activities [4]. The increased quantity of phenolic in Chilli may be attributed to resistance to viral infection [5]. Phenolics inhibit diseases development through inhibition of exteracellular enzymes and antioxidant activity in plant tissue [6].

This study describes the antibacterial and antiviral properties of five medicinal plants. Nigella sativa L., (Black seed) plant is an annual herb of the Ranunculaceae family. The seeds contain volatile and fixed oil which are used in pharmaceutical industry. The extracts of the seeds have been shown to possess antioxidant, anticancer and antimicrobial activities [7]. Broad bean mosaic virus was inhibited by the extracts of Nigella sativa and Zizyphus plants [8].

Syzygium aromaticum (Clove) is the aromatic dried flower buds of a tree in the family Myrtaceae. Cloves are antimutagenic, antiinflammatory, antioxidant, antiulcerogenic and antiparasitic [9]. Several studies have demonstrated potent antifungal, antiviral and antibacterial effects of clove $[10,11]$.
Thymus vulgaris (Thyme), locally known as zaatar, belonging to family Lamiaceae; The aromatic and medicinal properties of the genus Thymus have made it one of the most popular plants all over the world. Thymol oil derived from thyme has demonstrated biological properties such as antimicrobial, antioxidant and antiseptic activities [12]. It has high activity on inhibition of respiratory tract pathogenic bacteria [13]. Generally, thyme species are commonly used as herbal tea, flavoring agent and medicinal plants [14].

Zingiber officinale (Ginger), belonging to the family Zingiberacae, is a perennial herb with thick tuberous rhizomes. The ginerols (an essential oil) have antibacterial properties [15]. Malu et al. [16] showed that ginger extracts have medicinal properties, antibacterial activity. Ginger inhibits the growth of Staphylococcus aureus and Streptococcus pyogenes [17].

Mentha piperita (Peppermint) belonging to family Labiate, and is of huge importance medicinally [18]. Peppermint leaves contain about $0.5-4 \%$ volatile oil. This oil is composed of $50-78 \%$ free methanol, monoterpene, menthofurane and traces of jasmine $(0.15 \%)$ to improve the quality [19]. Peppermint has antibacterial, antiviral and fungicidal activity [20].

Therefore, the objective of this study was to assess antibacterial

${ }^{*}$ Corresponding author: Abdel-Shafi S, Botany and Microbiology Department, Faculty of Science, Zagazig University, Egypt, E-mail: hegazyseham@yahoo. com

Received July 05, 2013; Accepted July 25, 2013; Published July 29, 2013

Citation: Abdel-Shafi S (2013) Preliminary Studies on Antibacterial and Antiviral Activities of Five Medicinal Plants. J Plant Pathol Microb 4: 190 doi:10.4172/21577471.1000190

Copyright: (C) 2013 Abdel-Shafi S. This is an open-access article distributed under the terms of the Creative Commons Attribution License, which permits unrestricted use, distribution, and reproduction in any medium, provided the original author and source are credited. 
activity of some medicinal plants on pathogenic bacteria, and investigate the antiviral activity of black seed against zucchini yellow mosaic virus, in vitro and in vivo on squash. Also, to evaluate the effect of the medicinal plants on morphological and physiological identity of squash mechanically infected with ZYMV.

\section{Materials and Methods}

\section{Medicinal plants}

Five medicinal plants, ginger, black seed, thyme, clove and peppermint were purchased from local market of Zagazig, Egypt.

\section{Preparation of infusion and decoction}

The aqueous infusion was prepared by taking $10 \mathrm{~g}$ of tested medicinal plants in $100 \mathrm{ml}$ distilled water and left for 24 hours at room temperature with occasional shaking, and filtered to obtain clear infusion. The aqueous decoction was prepared by boiling $10 \mathrm{~g}$ of tested medicinal plants in $100 \mathrm{ml}$ distilled water in a flask for 20 minutes. The flask was removed from heat and allowed to cool. The content of flask was filtered to obtain clear decoction [21].

\section{Tested microorganisms}

Bacterial species: Six bacterial species belonging to Gram-negative and Gram-positive were tested. Staphylococcus aureus, Pseudomonas aeruginosa, Escherichia coli were obtained from Faculty of Medicine, Zagazig University, while Listeria monocytogenes, Lactococcus lactis and Bacillus cereus were obtained from Faculty of Science, Zagazig University.

\section{Sources of antibacterials}

Infusion and decoction of ginger, black seed, thyme, clove and mentha.

Screening of antibacterial activity: Screening of antibacterial activity was performed by standard disc diffusion method [22]. Fifty sterilized discs of filter paper (6 mm diameter) were soaked in $1 \mathrm{ml}$ of infusion or decoction, separately, for 2 minutes and then used for screening. The potency of each disc was $10 \mu \mathrm{l}$ (each 50 discs of filter paper absorbed $0.5 \mathrm{ml}$ ). Nutrient agar was used as base medium. The inoculated plates were incubated at $37^{\circ} \mathrm{C}$ for 24 hours. After incubation, inhibition zone diameters of 4 discs for each treatment were measured to the nearest millimeter $(\mathrm{mm})$.

Zucchini Yellow Mosaic Virus (ZYMV) isolated from naturally infected zucchini fruit: This virus was identified by Abdel-Shafi [23], by double antibody sandwich enzyme linked immunosorbent assay (DAS-ELISA), as described by Clark and Adams [24]. The virus was propagated and maintained in squash plants (Cucurbita pepo L.), according to Faccioli and Capponi [25], $5 \mathrm{~g}$ of mechanically infected squash leaves were ground in sterile morter with a pestle in $10 \mathrm{ml}$ of 0.01 $\mathrm{M}$ phosphate buffer solution of $\mathrm{pH} 7.2$, then filtered by cotton piece. The volume was made up to $20 \mathrm{ml}$ with phosphate buffer, then $100 \mu \mathrm{l}$ of viral sap were mechanically inoculated into coteledonary leaves and first leaf of squash dusted by carborundum (600 mesh-Prolab). Then, wash the inoculated leaves by distilled water according to Yarwood [26]. After 21 days, the symptoms were recorded and the infected leaves were frozen and used as inocula in further experiments.

Squash seeds (Host plant): Squash seeds (Cucurbita pepo L.), were obtained from Agriculture Research Institute, Giza, Egypt, were cultivated in plastic pots $\left(1000 \mathrm{~cm}^{3}\right)$ one $\mathrm{cm}$ depth below the soil surface and kept under the natural day light in greenhouse of Faculty of Science, Zagazig University.

\section{Sources of antivirals}

Infusion and decoction of Nigella sativa seeds.

\section{Screening of antiviral activity}

In vitro studies: ( $2 \mathrm{ml}$ of sap containing virus $+2 \mathrm{ml}$ of NS seeds extraction mixed in test tubes for $15 \mathrm{~min}$.). Equal volumes of infusion or decoction and ZYMV inoculums were mixed together, then 100 $\mu \mathrm{l}$ of the mixture after dusting the leaves with carborundum $(600$ meshes, Prolab), inoculated directly into cotyledonary leaves and first leaf of Cucurbita pepo L., then the inoculated leaves were washed with distilled water. The numbers of plants which have symptoms were counted after 21 days and the mean of 20 plants/treatment was calculated. General control plants (healthy plants) were inoculated with buffer only. Viral control plants were inoculated by ZYMV only. The percentage of inhibition calculated according to the equation: \% of viral inhibition=number of symptomatic plants in viral control-number of symptomatic plants in treatment/number of symptomatic plants in viral control $\times 100$. Plants were harvested, and then number of leaves, shoot length and fresh weight were determined.

\section{In vivo studies}

Post inoculation experiment (NS seed extraction treatment after 24 hrs from viral infection): After $24 \mathrm{hrs}$ of virus inoculation, the leaves were treated with NS seeds infusion and decoction $100 \mathrm{ul} /$ leaf. The developing symptoms were recorded after 21 days ( 20 plants for each treatment), and the percentages of inhibition were calculated. The viral control (squash plants inoculated with ZYMV only) and the general control (healthy plants treated with phosphate buffer) were done. Plants were harvested, and then number of leaves, shoot length and fresh weight were determined.

Pre-inoculation experiment (NS extraction treatment before $\mathbf{2 4} \mathrm{hrs}$ from viral infection): Before $24 \mathrm{hrs}$. of virus inoculation, the leaves were treated with NS seeds infusion and decoction $100 \mathrm{ul} / \mathrm{leaf}$. The symptoms were recorded after 21 days ( 20 plants/treatment), and the percentages of inhibition were calculated.

Seed treatment experiment: The squash seeds were soaked in NS extracts for 6,12 and $24 \mathrm{hrs}$, then the seeds germinated in the pots. After germination, the cotyledonary leaves and first leaf which were dusted by carborundum inoculated with ZYMV inoculums $(100 \mu \mathrm{l} /$ leaf), then the inoculated leaves were rinsed with distilled water. The viral control is squash seeds soaked in distilled water for 6, 12 and 24 hrs, then germinated and mechanically inoculated with virus inoculum only. Plants were harvested, and then the number of leaves, shoot length and fresh weight were determined.

\section{Methods used for antioxidant investigation}

Estimation of phenolic compounds: Extraction of free and bound cell wall phenols: Free phenols were extracted from plant material of both control and treated plants according to the method of Campbell and Ellis [27]. Phenolic acids esterified to the cell wall by ester linkages were saponified, according to the method of Funk and Brodelius [28]. The mixtures were neutralized with $2 \mathrm{M} \mathrm{HCl}$, centrifuged, and the supernatant also was used for Folin-Ciocalteu assay.

Determination of phenols by Folin-Ciocalteu assay: Phenolic content of the methanolic and $\mathrm{NaOH}$ extracts, described above, was determined by the method of Julkunen-Tiitto [29]. 
Citation: Abdel-Shafi S (2013) Preliminary Studies on Antibacterial and Antiviral Activities of Five Medicinal Plants. J Plant Pathol Microb 4: 190 doi:10.4172/2157-7471.1000190

Page 3 of 8

Estimation of antioxidant enzymes (polyphenol oxidase and peroxidase): Extraction: A known fresh weight of plant material was homogenized in $0.05 \mathrm{M}$ cold phosphate buffer ( $\mathrm{pH} 6.5$ ) and centrifuged at $10.000 \mathrm{rpm}$ for $10 \mathrm{~min}$. The supernatant was completed to total known volume and used as enzyme source [30].

Assay of polyphenol oxidase activity (PPO): The optical density of the produced color was measured at $430 \mathrm{~nm}$ using spectrophotometer (WP 0803006), and the enzyme activity was expressed as the change in the optical density/mg protein/min.

Assay of peroxidase activity (POX): Five $\mathrm{ml}$ of assay mixture comprising $300 \mu \mathrm{M}$ of phosphate buffer ( $\mathrm{pH} 6.8$ ), $50 \mu \mathrm{M}$ catechol, 50 $\mu \mathrm{M} \mathrm{H}_{2} \mathrm{O}_{2}$ and $1 \mathrm{ml}$ crude enzyme were prepared. After incubation at $25^{\circ} \mathrm{C}$ for $5 \mathrm{~min}$, the reaction was stopped by the addition of $1 \mathrm{ml} 10 \%$ (v/v) $\mathrm{H}_{2} \mathrm{SO}_{4}$. The optical density of the produced color was measured at $430 \mathrm{~nm}$ using spectrophotometer (WP 0803006), and the enzyme activity was expressed as the change in the optical density/mg protein/ min.

Determination of total soluble protein content: The total soluble protein content was determined according to the method of Lowry et al. [31].

Statistical analysis: Data of the experiment were statistically analyzed using the General Linear Model Program of SAS [32]. Significant differences between treatment means were tested by Duncan's Multiple Range Test [33].

\section{Results}

The current work was designed to evaluate the effect of five medicinal plants on pathogenic bacteria, and on ZYMV infectivity in vitro and in vivo.

\section{The effect of aqueous infusion and decoction of five medicinal plants on pathogenic bacteria}

Results obtained in the present study revealed that the tested five medicinal plants extracts have potential antibacterial activity against all tested bacteria, except thyme against Staphylococcus aureus. Table 1 presents the results of antibacterial activity of aqueous infusion of five medicinal plants.

The aqueous infusion of ginger exhibited maximum activity against $E$. coli with $15.00 \mathrm{~mm}$ mean diameter of inhibition zone (IZ), compared to other medicinal plants. Also, the infusion of black cumin seeds showed highest antibacterial activity against Lactococcus lactis, Pseudomonas aeruginosa, Listeria monocytogenes and Staphylococcus aureus, with 22.30, 9.60, 9.50 and $9.00 \mathrm{~mm}$, respectively. The results in Table 2 showed that decoction of peppermint exhibited significant inhibition against E. coli and Lactococcus lactis (20 and $19.5 \mathrm{~mm}$, respectively), while decoction of black seeds showed maximum inhibition against $P$. aeruginosa and $B$. cereus with 9.50 and $9.3 \mathrm{~mm}$ compared to other medicinal plants. The decoction of clove inhibited Listeria monocytogenes and Staphylococcus aureus significantly compared to other plants. This means the most potent medicinal plants was black seeds extract; therefore, further antiviral screening was done.

\begin{tabular}{|c|c|c|c|c|c|}
\hline \multirow[t]{2}{*}{ Tested bacteria } & \multicolumn{5}{|c|}{ Mean zone of inhibition $(\mathrm{mm}) \pm \mathrm{SD}$} \\
\hline & Ginger & Black cumin & Thyme & Clove & peppermint \\
\hline \multicolumn{6}{|l|}{ Gram-negative: } \\
\hline E. coli & $15.00 \pm .78^{a}$ & $2.00 \pm 0.14^{d}$ & $8.00 \pm .14^{b}$ & $2.00 \pm 0.12^{\mathrm{d}}$ & $5.00 \pm .19^{c}$ \\
\hline Pseudomonas aeruginosa & $4.00 \pm 0.18^{c}$ & $9.60 \pm 0.15^{\mathrm{a}}$ & $9.00 \pm .12^{\mathrm{a}}$ & $6.60 \pm 0.12^{b}$ & $4.00 \pm 0.15^{c}$ \\
\hline \multicolumn{6}{|l|}{ Gram-postive: } \\
\hline Bacillus cereus & $11.60 \pm 0.43^{a}$ & $5.00 \pm 0.14^{\mathrm{e}}$ & $8.30 \pm 0.22^{c}$ & $9.30 \pm 0.22^{\mathrm{b}}$ & $7.00 \pm .10^{\mathrm{d}}$ \\
\hline Lactococcus lactis & $11.00 \pm 0.22^{c}$ & $22.30 \pm 0.50^{a}$ & $7.30 \pm .15^{\mathrm{d}}$ & $7.60 \pm 0.19^{d}$ & $16.00 \pm 28^{b}$ \\
\hline Listeria monocytogens & $9.00 \pm 0.18^{b}$ & $9.50 \pm 0.22^{\mathrm{a}}$ & $9.00 \pm 0.23^{b}$ & $8.30 \pm 0.21^{c}$ & $6.30 \pm .18^{\mathrm{d}}$ \\
\hline Staphylococcus aureus & $5.70 \pm 0.20^{c}$ & $9.00 \pm 0.1^{\mathrm{a}}$ & $0.00 \pm 0.0^{d}$ & $0.00 \pm 0.0^{\mathrm{d}}$ & $6.33 \pm 0.15^{\mathrm{b}}$ \\
\hline
\end{tabular}

$a, b, c, d$ means in the same row with different superscript differ significantly $(p<0.05)$

Table 1: Antibacterial activities of infusion of medicinal plants.

\begin{tabular}{|c|c|c|c|c|c|}
\hline \multirow[t]{2}{*}{ Tested bacteria } & \multicolumn{5}{|c|}{ Mean zone of inhibition $(\mathrm{mm}) \pm \mathrm{SD}$} \\
\hline & Ginger & Black cumin & Thyme & Clove & peppermint \\
\hline \multicolumn{6}{|l|}{ Gram-negative: } \\
\hline E. coli & $7.30 \pm 0.11^{d}$ & $5.30 \pm 0.11^{e}$ & $11.30 \pm 0.55^{\mathrm{b}}$ & $9.30 \pm 0.15^{c}$ & $20.00 \pm 0.26^{a}$ \\
\hline Pseudomonas aeruginosa & $8.00 \pm 0.15^{c}$ & $9.50 \pm 0.41^{a}$ & $7.30 \pm 0.17^{d}$ & $3.00 \pm 0.14^{e}$ & $8.70 \pm 0.20^{b}$ \\
\hline \multicolumn{6}{|l|}{ Gram-postive: } \\
\hline Bacillus cereus & $4.30 \pm 0.11^{\mathrm{e}}$ & $9.30 \pm 0.15^{\mathrm{a}}$ & $8.30 \pm 0.22^{c}$ & $5.00 \pm 0.20^{d}$ & $7.00 \pm 0.10^{b}$ \\
\hline Lactococcus lactis & $13.00 \pm 0.19^{b}$ & $8.30 \pm 0.35^{c}$ & $7.30 \pm .15^{\mathrm{d}}$ & $5.00 \pm 0.16^{e}$ & $19.50 \pm 1.00^{\mathrm{a}}$ \\
\hline Listeria monocytogens & $12.30 \pm 0.22^{\mathrm{c}}$ & $7.00 \pm 0.11^{d}$ & $9.00 \pm 0.23^{b}$ & $14.30 \pm 0.22^{\mathrm{a}}$ & $13.00 \pm 0.30^{\mathrm{b}}$ \\
\hline Staphylococcus aureus & $0.00 \pm 0.0^{b}$ & $0.00 \pm 0.0^{\mathrm{b}}$ & $0.00 \pm 0.0^{d}$ & $4.00 \pm 0.18^{a}$ & $0.00 \pm 0.0^{\mathrm{b}}$ \\
\hline
\end{tabular}

$a, b, c, d$ means in the same row with different superscript differ significantly $(p<0.05)$

Table 2: Antibacterial activities of decoction of medicinal plants. 
Citation: Abdel-Shafi S (2013) Preliminary Studies on Antibacterial and Antiviral Activities of Five Medicinal Plants. J Plant Pathol Microb 4: 190 doi:10.4172/2157-7471.1000190

Page 4 of 8

\section{In vitro and in vivo screening of antiviral activities of Nigella sativa on ZYMV}

The effect of aqueous infusion and decoction of Nigella sativa seeds on inhibition of ZYMV symptoms is present in Figure 1. The results of in vitro exp. revealed that decoction and infusion of NS seeds inhibit the ZYMV symptoms on squash plants by $85 \%$ and $80 \%$, respectively. In post experiment decoction and infusion gave 70 and 65\% ZYMV inhibition, respectively (Figure 1). The observed symptoms on

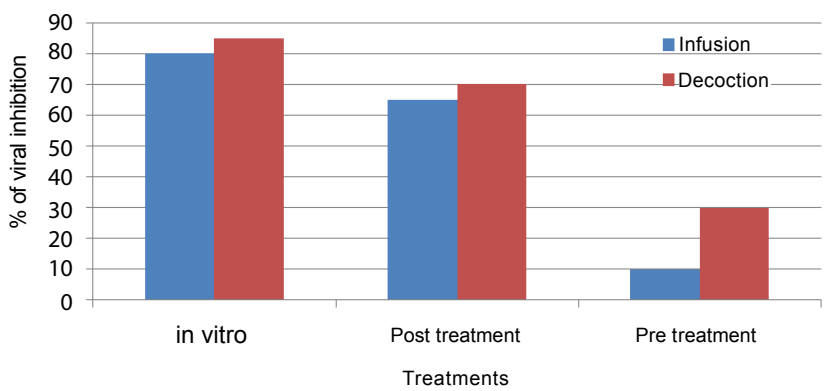

Figure 1: Antiviral activity of Infusion and Decoction of black seed extraction on the infectivity of ZYMV on squash plants in-vitro and in-vivo. \% of inhibition=mean of three reading, Healthy control=untreated plants, vira control $=0 \%$ inhibition (all plants are diseased)

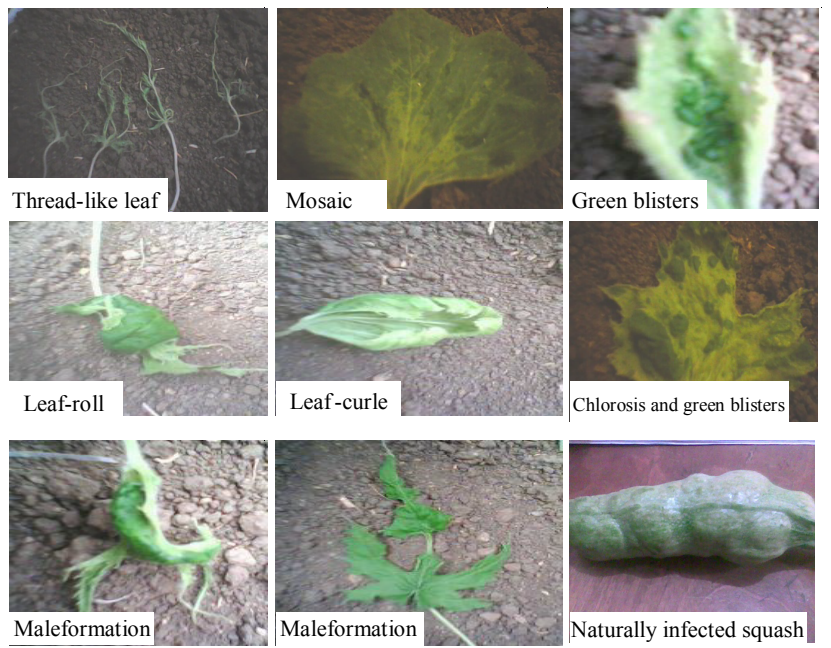

Figure 2: ZYMV Symptoms on mechanically infected squash leaves and on naturally infected squash (Unmarketable).
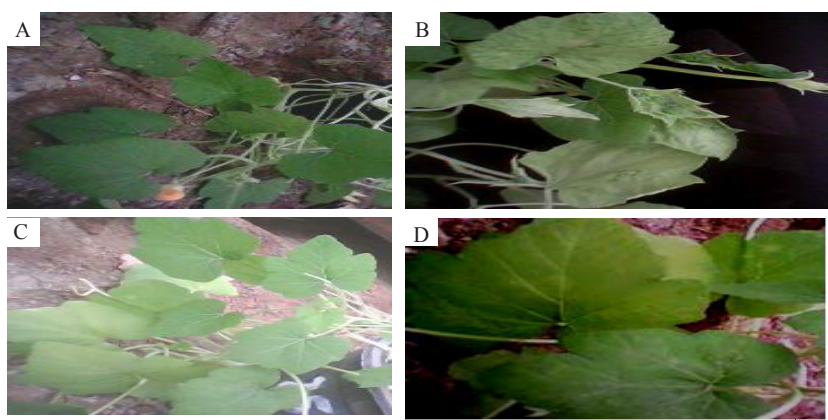

Figure 3: A-Healthy squash plants control, B-Viral control, C and D, Decoction a infusion of black seeds ( in vitro exp.), respectively, the treatment inhibit virus symptoms and increase the plant growth. mechanically inoculated squash plants, including malformation, dark green blisters, thread-like leaf, mosaic, leaf roll, abnormal leaf shape and chlorosis (Figure 2). Also, the application of infusion and decoction of black seeds not only inhibit the virus symptoms, but also, increase the leaf size (Figure 3), and the growth parameter of squash plants (Table 3 ) in comparison with mechanically infected viral control and healthy control plants.

\section{Soaking of squash seeds in decoction and infusion of black seeds}

The results in Figure 4 showed that the soaking of squash seeds in decoction exhibited higher activity against ZYMV than infusion. The decoction showed maximum percentage of viral inhibition (95\%) after

\begin{tabular}{|c|c|c|c|c|}
\hline Treatments & $\begin{array}{l}\text { Healthy } \\
\text { control }\end{array}$ & Viral control & $\begin{array}{l}\text { Decoction of } \\
\text { black seed }\end{array}$ & $\begin{array}{l}\text { Infusion of } \\
\text { black seed }\end{array}$ \\
\hline \multicolumn{5}{|c|}{ In vitro } \\
\hline No. of leaves & $7.01 \pm 0.74^{\mathrm{b}}$ & $6.20 \pm 0.63^{b}$ & $8.60 \pm 1.70^{\mathrm{a}}$ & $8.2 \pm 1.40^{\mathrm{a}}$ \\
\hline Shoot length $(\mathrm{cm})$ & $30.00 \pm 3.09^{b}$ & $29.6 \pm 3.69^{b}$ & $42.6 \pm 8.37^{\mathrm{a}}$ & $39.6 \pm 5.52^{\mathrm{a}}$ \\
\hline Fresh weight $(\mathrm{g})$ & $10.13 \pm 2.51^{b}$ & $7.92 \pm 1.95^{b}$ & $11.63 \pm 2.02^{\mathrm{a}}$ & $12.53 \pm 2.60^{a}$ \\
\hline \multicolumn{5}{|c|}{ Pre inoculation treatment } \\
\hline No. of leaves & $5.5 \pm 0.53 \mathrm{bc}$ & $5.00 \pm 0.82^{c}$ & $8.7 \pm 0.48^{a}$ & $6.00 \pm 0.82^{b}$ \\
\hline Shoot length $(\mathrm{cm})$ & $35.00 \pm 4.11^{\mathrm{a}}$ & $26.6 \pm 3.06$ & $35.00 \pm 0.84^{a}$ & $30.00 \pm 5.23^{b}$ \\
\hline Fresh weight $(\mathrm{g})$ & $10.77 \pm 1.81^{\mathrm{a}}$ & $5.86 \pm 1.71^{c}$ & $12.00 \pm 5.23^{a}$ & $11.92 \pm 1.22^{\mathrm{a}}$ \\
\hline \multicolumn{5}{|c|}{ Post inoculation treatment } \\
\hline No. of leaves & $5.5 \pm 0.53^{\mathrm{bc}}$ & $5.00 \pm 0.82^{c}$ & $7.40 \pm 0.52^{\mathrm{a}}$ & $5.70 \pm 0.48^{b}$ \\
\hline Shoot length $(\mathrm{cm})$ & $35.00 \pm 4.11^{\mathrm{a}}$ & $26.6 \pm 3.06^{c}$ & $31.40 \pm 3.37^{\mathrm{b}}$ & $32.8 \pm 4.24^{\mathrm{ab}}$ \\
\hline Fresh weight (g) & $10.77 \pm 1.81^{\mathrm{a}}$ & $5.86 \pm 1.71^{d}$ & $8.72 \pm 0.58^{b}$ & $7.20 \pm 0.98^{c}$ \\
\hline
\end{tabular}

Healthy control=twenty plants normal (without any treatments) all are healthy. Viral control=squash seedling mechanically inoculated with ZYMV on cotyledonary leaves and first stage leaves.

$a, b, c, d$ means in the same row with different superscript differ significantly $(p<0.05)$ Table 3: Effect of black seed extraction in vitro and in vivo on growth parameters of mechanically infected squash plants by ZYMV. (Each value is the mean twenty reading $\pm S D$ ).

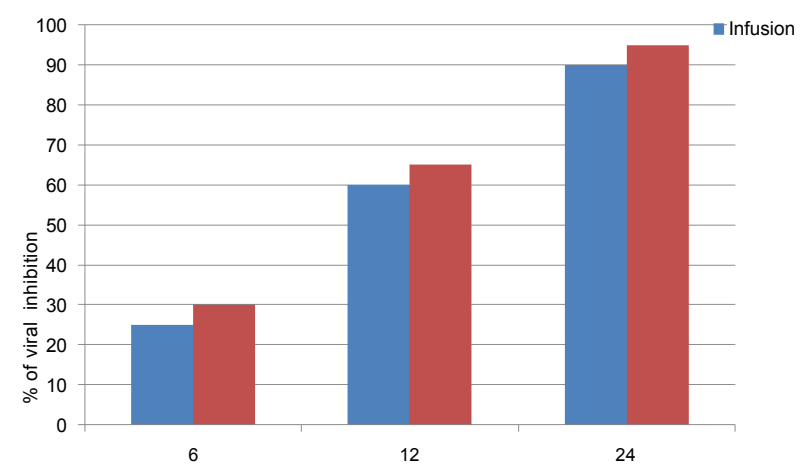

Figure 4: Effect of soaking of squash seeds in Decoction and Infusion of black seed extraction on the infectivity of ZYMV on squash plants at different time intervals.

$\%$ of inhibition=mean of three reading, Healthy control=untreated plants, vira control $=0 \%$ inhibition (all plants are diseased). 
Citation: Abdel-Shafi S (2013) Preliminary Studies on Antibacterial and Antiviral Activities of Five Medicinal Plants. J Plant Pathol Microb 4: 190 doi:10.4172/2157-7471.1000190

Page 5 of 8

\begin{tabular}{|c|c|c|c|c|c|c|c|c|c|}
\hline \multirow{2}{*}{$\begin{array}{ll} & \text { Time } \\
\text { Treatment } & \end{array}$} & \multicolumn{3}{|c|}{$6 \mathrm{hrs}$} & \multicolumn{3}{|c|}{$12 \mathrm{hrs}$} & \multicolumn{3}{|c|}{$24 \mathrm{hrs}$} \\
\hline & No. of leaves & $\begin{array}{l}\text { Shoot length } \\
\text { (cm) }\end{array}$ & \begin{tabular}{|c|} 
Fresh weight \\
(g)
\end{tabular} & No. of leaves & $\begin{array}{c}\text { Shoot length } \\
\text { (cm) }\end{array}$ & $\begin{array}{c}\text { Fresh weight } \\
\text { (g) }\end{array}$ & No. of leaves & $\begin{array}{l}\text { Shoot length } \\
\text { (cm) }\end{array}$ & $\begin{array}{l}\text { Fresh weight } \\
\text { (g) }\end{array}$ \\
\hline Healthy control & $6.20 \pm 0.79^{c}$ & $36.7 \pm 2.79^{a}$ & $10.4 \pm 1.64^{\mathrm{a}}$ & $6.20 \pm 0.79^{c}$ & $36.7 \pm 2.79^{a}$ & $10.37 \pm 1.64^{a}$ & $6.20 \pm 0.79^{b}$ & $36.7 \pm 2.79^{a}$ & $10.37 \pm 1.64^{\mathrm{a}}$ \\
\hline Viral control & $4.70 \pm 0.67^{d}$ & $26.6 \pm 3.06^{b}$ & $4.89 \pm 0.64^{\circ}$ & $4.70 \pm 0.67^{d}$ & $26.60 \pm 3.06^{c}$ & $4.89 \pm 0.64^{c}$ & $4.70 \pm 0.67^{c}$ & $26.60 \pm 3.06^{c}$ & $4.89 \pm 0.64^{c}$ \\
\hline Infusion of black seeds & $7.70 \pm 0.48^{b}$ & $34.10 \pm 3.73^{a}$ & $6.76 \pm 0.96^{b}$ & $7.20 \pm 1.03^{b}$ & $31.9 \pm 2.73^{\mathrm{b}}$ & $7.25 \pm 1.18^{\mathrm{b}}$ & $7.1 \pm 1.20^{\mathrm{a}}$ & $32.3 \pm 4.00^{\mathrm{b}}$ & $8.95 \pm 1.12^{b}$ \\
\hline $\begin{array}{l}\text { Decoction of black } \\
\text { seeds }\end{array}$ & $8.50 \pm 0.97^{b}$ & $33.70 \pm 2.98^{a}$ & $7.39 \pm 1.02^{\mathrm{b}}$ & $8.00 \pm 0.94^{\mathrm{a}}$ & $31.40 \pm 2.76^{b}$ & $7.49 \pm 1.66^{b}$ & $7.8 \pm 0.92^{\mathrm{a}}$ & $35.20 \pm 3.08^{\mathrm{ab}}$ & $9.66 \pm 1.14^{\mathrm{ab}}$ \\
\hline
\end{tabular}

$a, b, c, d$ means in the same column with different superscript differ significantly $(p<0.05)$

Table 4: Effect of squash seeds soaking in black seed Infusion and Decoction extraction on growth parameters of treated plants with ZYMV at different time intervals.

\begin{tabular}{|c|c|c|c|c|c|c|}
\hline Treatments & $\begin{array}{l}\text { Free phenolic } \\
\text { compounds }\end{array}$ & $\begin{array}{l}\text { Cell bound phenolic } \\
\text { compounds }\end{array}$ & Total phenols & Total protein & Polyphenol oxidase & Peroxidase \\
\hline \multicolumn{7}{|c|}{ In vitro experiment } \\
\hline Viral control & 21.67 & 8.21 & 29.88 & 9.60 & 0.0493 & 0.0410 \\
\hline Healthy control & 26.25 & 7.23 & 33.48 & 8.80 & 0.0330 & 0.0323 \\
\hline Infusion & 27.50 & 9.13 & 36.63 & 10.50 & 0.0500 & 0.0501 \\
\hline Decoction & 31.30 & 9.50 & 40.80 & 11.10 & 0.0551 & 0.0600 \\
\hline \multicolumn{7}{|c|}{ Pre-inoculation experiment } \\
\hline Viral control & 19.33 & 11.23 & 30.56 & 9.50 & 0.0482 & 0.0400 \\
\hline Healthy control & 24.50 & 8.49 & 32.99 & 8.49 & 0.0312 & 0.0301 \\
\hline Infusion & 25.39 & 8.23 & 34.67 & 9.76 & 0.0481 & 0.0419 \\
\hline Decoction & 29.78 & 8.97 & 35.99 & 10.88 & 0.0523 & 0.0557 \\
\hline \multicolumn{7}{|c|}{ Post-inoculation experiment } \\
\hline Viral control & 20.35 & 9.22 & 29.57 & 9.30 & 0.0490 & 0.0422 \\
\hline Healthy control & 23.45 & 7.99 & 31.44 & 8.70 & 0.0340 & 0.0313 \\
\hline Infusion & 26.91 & 8.99 & 35.26 & 9.87 & 0.0477 & 0.0450 \\
\hline Decoction & 30.21 & 9.30 & 37.22 & 10.97 & 0.0548 & 0.0569 \\
\hline
\end{tabular}

Viral control: Mechanically infected squash plants with ZYMV. Healthy plants: squash plants without any treatments

Table 5: The influence of Nigella sativa infusion and decoction on phenolic compounds ( $\mathrm{mg} / \mathrm{g})$, total protein, polyphenol oxidase and peroxidase of ZYMV infected squash plants in vitro and in vivo.

soaking for $24 \mathrm{hrs}$, while infusion gave $90 \%$ inhibition after soaking for $24 \mathrm{hrs}$. Moreover, results of the growth parameters of plants in seed soaking experiments in Table 4 revealed that number of leaves, shoot length and fresh weight increased significantly $(\mathrm{p}<0.05)$ more than the viral control at all times. The decoction increases the growth parameters more than infusion. Soaking in decoction for $24 \mathrm{hrs}$, give number of leaves, shoot length and fresh weight 7.8, 35.2, 9.66 compared to 4.7, 26.6 , and 4.89 of viral control.

The physiological responses of squash plants infected with ZYMV and treated by aqueous infusion and decoction of Nigella sativa seeds

Data shown in Table 5 and 6 showed that in vitro application of infusion and decoction of Nigella sativa seeds led to an increase in total phenols contents of squash plants compared to viral or healthy control plants. The application of NS decoction increased the total phenolic compounds in all experiments compared to viral control. The total soluble intracellular protein significantly increased upon treatment with infusion and decoction of Nigella sativa seeds comparing to viral control where it was $10.50,11.10$ compared to 8.8 , respectively. As well as, the activity of polyphenol oxidase and peroxidase increased after NS extracts treatment, comparing to viral and healthy control plants. The infusion treatment for $24 \mathrm{hrs}$ leads to total phenol 30.73; total protein 9.01; polyphenol oxidase 0.0388 and peroxidase 0.0391 . The decoction treatment for $24 \mathrm{hrs}$ leads to total phenol 32.17; total protein 10.1; polyphenol oxidase 0.0533 and peroxidase 0.0490 .

\section{Discussion}

It is important to find safe and cheap effective antimicrobial agents to inhibit virus and pathogenic bacteria. The virus and bacteria cannot mutate with the medicinal plants because of their chemical constituents. One essential oil of these plants can have from 200-800 chemical constituents. Due to increasing antibiotic resistance in microorganisms and side effects of synthetic antibiotics, medicinal plants are now gaining popularity in treatment of bacterial infections [34]. Medicinal plants are a rich source of antimicrobial agents due to the secondary metabolites such as alkaloids, flavonoides, tannins and terpenoids that are present in these plants $[35,36]$.

Plants are important source of potentially useful structures for new chemotherapeutic agents. The first step towards this goal is the in vitro antibacterial activity assay [37]. In the present study, the results for the antibacterial screening have shown that the infusion of ginger significantly $(\mathrm{p}<0.05)$ inhibit $E$. coli and Bacillus cereus compared to other medicinal plants. This result agrees with that obtained by Ekweny and Elegalam [38], who reported that ginger inhibit E. coli. Also, Malu et al. [16] reported that ginger extracts possesses antibacterial properties and could be used for the treatment of bacterial infections.

This study showed that the infusion and decoction of black 


\begin{tabular}{|c|c|c|c|c|c|c|}
\hline Treatments & $\begin{array}{l}\text { Free phenolic } \\
\text { compounds }\end{array}$ & $\begin{array}{l}\text { Cell bound phenolic } \\
\text { compounds }\end{array}$ & Total phenols & Total protein & Polyphenol oxidase & Peroxidase \\
\hline Viral control & 20.22 & 11.19 & 30.56 & 10.20 & 0.0499 & 0.0402 \\
\hline Healthy control & 20.66 & 9.76 & 30.42 & 9.30 & 0.0410 & 0.0403 \\
\hline $\begin{array}{l}\text { Soaking in Infusion for } \\
6 \mathrm{hrs} \\
12 \mathrm{hrs} \\
24 \mathrm{hrs}\end{array}$ & $\begin{array}{l}19.25 \\
9.70 \\
19.9\end{array}$ & $\begin{array}{l}10.72 \\
11.00 \\
10.83\end{array}$ & $\begin{array}{l}29.97 \\
20.70 \\
30.73\end{array}$ & $\begin{array}{l}9.60 \\
9.23 \\
9.01\end{array}$ & $\begin{array}{l}0.0371 \\
0.0383 \\
0.0388\end{array}$ & $\begin{array}{l}0.0400 \\
0.0392 \\
0.0391\end{array}$ \\
\hline $\begin{array}{l}\text { Soaking in decoction for } \\
6 \mathrm{hrs} \\
12 \mathrm{hrs} \\
24 \mathrm{hrs}\end{array}$ & $\begin{array}{l}19.98 \\
20.15 \\
20.50\end{array}$ & $\begin{array}{l}10.87 \\
11.66 \\
11.67\end{array}$ & $\begin{array}{l}30.85 \\
31.81 \\
32.17\end{array}$ & $\begin{array}{c}9.99 \\
10.00 \\
10.10\end{array}$ & $\begin{array}{l}0.0500 \\
0.0510 \\
0.0533\end{array}$ & $\begin{array}{l}0.0452 \\
0.0477 \\
0.0490\end{array}$ \\
\hline
\end{tabular}

Viral control: Mechanically infected squash plants with ZYMV. Healthy plants: Squash plants without any treatments

Table 6: Effect of soaking in Nigella sativa infusion and decoction on phenolic compounds (mg/g), total protein, polyphenol oxidase and peroxidase of ZYMV infected squash plants

seed strangely inhibited Lactococcus lactis, P. aeruginosa, Listeria monocytogenes and Staphylococcus aureus with 22.30, 9.60, 9.50 and $9.00 \mathrm{~mm}$, respectively. These results agree with that reported by Mashhadian and Rakhshandeh [39]. Black seed extracts have weak antibacterial activity on E. coli. Similar results obtained by Zuridah et al. [40]. Aqueous decoction and infusion of black seed inhibit the production of ZYMV symptoms on squash plants by $85 \%$ and $80 \%$, respectively, in vitro treatment. Soaking in NS decoction and infusion for $24 \mathrm{~h}$ inhibited ZYMV by $95 \%$ and $90 \%$, respectively. These results are similar to previous studies. Mohamed [8] showed that the extract of NS inhibited the infectivity of Broad bean mosic virus (BBMV) in vitro and in vivo. NS infusion and decoction not only inhibit ZYMV symptoms, but also increase the growth parameters. The application of NS extract improved antioxidant response of squash plant in terms of phenolic compounds, total soluble proteins, polyphenol oxidase and peroxidase, which were summarized in Tables 5 and 6 . The accumulation of the phenolic compounds and their derivatives may be considered as a defense mechanism or as a hypersensitive reaction. The disease resistance response correlates with changes in cell biochemistry and physiology [41]. Many studies showed that induced resistance through the accumulation of various phenolic compounds and activation of oxidative and key enzymes in phenylpropanoid and isoflavonoid pathways [42].

In this study, it was found that the peroxidase enzyme and polyphenol-oxidase enzyme activities showed an increase in the infected plants. Moreover, the activity of such enzymes was higher in the plants treated with infusion and decoction of black seed. These results could give an explanation for the increase in phenolic compounds, since the oxidative enzymes play an important role in oxidation of free phenols, which are accumulated as a result of viral infection, and these newly synthesized polyphenols and their oxidation products may limit the viral activity in resistance tissues. Similarly, many studies observed an increase activity in peroxidase, catalase and polyphenoloxidase in the infected plants $[43,44]$. Accumulation of such compounds and the high activity of some enzymes involved in the metabolism of ROS, such as peroxidase (POX) and polyphenol oxidase explain the reduction in viral disease symptoms, and the increase in growth and metabolic activities in squash plant treated with NS infusion and decoction, which activate the biochemical and structural defense systems that help word off the spread of pathogen, and consequently, increase squash growth if compared to the ZYMV infected ones. These results agree with that obtained by Ghosal et al. [45] and Devanathan et al. [46].

Recently, it was found that a common feature of abiotic and biotic stress factors is the generation of ROS, such as $\mathrm{H}_{2} \mathrm{O}_{2}$ in plant cell ROS formation also accompanies normal metabolic processes. To ameliorate the danger posed by the presence of cellular oxidants, plant cells have evolved complex defense mechanisms [47]. Plants possess several mechanisms that detoxify $\mathrm{O}_{2}$ and $\mathrm{H}_{2} \mathrm{O}_{2}$ called antioxidant systems. The primary components of antioxidant systems include non-enzymatic antioxidants (carotenoids, ascorbate, glutathione and tocopherols), and enzymes such as catalase, glutathione peroxidase and those involved in the ascorbate glutathione cycle; ascorbate peroxidase, dehydroascorbate reductase, monodhydroascorbate reductase and glutathione reductase. The components of these antioxidant defense systems can be found in different sub cellular compartments [48,49]. Virus infection has also been shown to increase peroxides [50]. (Although phenolic compounds do not have any known nutritional function, they may be important to human health because of their antioxidant potency [51]. The free and total phenols were more concentrated in leaves of squash plants after black seed treatments compared to viral control, and this was in contrast with bound phenols. These results were in agreement with Kofalvi and Nassuth [52], who reported a significant increase in phenols accumulation in wheat plants infected with the wheat streak mosaic potyvirus (WSMV) compared to the healthy controls. Phenolic compounds produced by plants are formed through phenylpropanoid metabolism. However, since free phenols can be cytotoxic in the cytoplasm, plants sequester these compounds in the vacuole or deposit them in or on the cell wall. Once the phenolic acids or cinnamyl alcohols reach the cell wall, they may be either esterified or linked to the cell wall polysaccharides or hemicelluloses, or be polymerized into lignin [53].

Squash plants infected with zucchini yellow mosaic virus (ZYMV) show high content of total protein compared to healthy plants. However, there was a progressive increase in protein contents in plants treated with mixture of NS and ZYMV. This result agreed with that obtained by Cheema et al. [54], who showed that protein content in two soybean varieties increased with infection with soybean yellow mosaic virus. Haque et al. [55] reported that ZYMV infection increased the protein content of pumpkin leaves compared to healthy ones. Muqit et al. [56] showed that total protein increased in the infected leaves of Benincasa hispida due to Papaya ring spot virus. Rao et al. [57] concluded that the increased protein content in virus infected plants was due to increased activity of RNA synthetase or RNA polymerase. The treated plants also show high protein content compared to viral control. This may be due to the formation of new antiviral protein. This agrees with that obtained by Abdel-Shafi [23].

The infusion and decoction of thyme inhibited all tested bacteria, except Staphylococcus aureus. Stahl-Biskup and Saez [14] reported that the extracts of Thymus species have strong antibacterial, antiviral, antifungal and antioxidant activities. This is similar with that obtained by Seden et al. [58], who reported that thyme inhibited the pathogenic 
Citation: Abdel-Shafi S (2013) Preliminary Studies on Antibacterial and Antiviral Activities of Five Medicinal Plants. J Plant Pathol Microb 4: 190 doi:10.4172/2157-7471.1000190

bacteria. Thymol oil derived from thyme (Thymus vulgaris), has demonstrated biological properties such as antimicrobial, antioxidant and antiseptic activities [12]. It has high activity on inhibition of respiratory tract pathogenic bacteria [13].

The infusion of clove inhibited all tested bacteria, except Stapylococcus aureus. This disagrees with that obtained by Saeed and Tariq [21]. The decoction of clove inhibited Listeria monocytogenes and Staphylococcus aureus significantly compared to other plants. The infusion of peppermint inhibited all tested bacteria, while the decoction exhibited significant inhibition against $E$. coli and Lactococcus lactis $(20$ and $19.5 \mathrm{~mm}$, respectively), but did not inhibit Staph aureus. Similar results were obtained by Irshad et al. [2], who reported that that plant peppermint inhibited 7 bacterial strains (E. coli, B. subtilis, S. typhi. $P$. aureus, K. pneumonia and S. epidermitus). Also, Saeed and Tariq [59] reported that the juice of peppermint leaves exhibited highest antibacterial activity.

Further work for quantitative analysis of virus and electron microscope will be done.

\section{Conclusion}

This study has shown that ginger, black seed, clove, thyme and peppermint extracts have antibacterial activity. Due to the increase of antibiotic resistant bacteria and bad effect of synthetic antibiotic, the decoction and infusion of medicinal plants above could be used as alternative to antibiotics in treatments of bacterial infections. Moreover, the infusion and decoction of black seeds showed high antiviral activity against ZYMV on squash plants. Black seed induce systemic resistance and defense response in squash against ZYMV infection, and increase the plant growth parameters. The enzymes involved in the defense against reactive oxygen species (ROS) showed an increase of POX, phenolic, polyphenol oxidase activities, compared to the control, suggesting a significant ROS decrease.

\section{References}

1. Ahmed I, Aquil F (2009) New strategies combating bacterial infection. WileyBlackwell, Weinheim, Germany.

2. Irshad S, Butt M, Younas $\mathrm{H}$ (2011) In vitro antibacterial activity of two medicinal plants Neem (Azadirachta indica) and peppermint. Intl R J of Pharmaceuticals 1: 9-14.

3. Reichling J, Schnitzler P, Suschke U, Saller R (2009) Essential oils of aromatic plants with antibacterial, antifungal, antiviral, and cytotoxic properties--An overview. Forsch Komplementmed 16: 79-90.

4. Dunkic V, Bezic N, Vuko E, Cukrov D (2010) Antiphytoviral activity of Satureja montana L. ssp. Variegate (host) P. W. Ball essential oil and phenol compounds on CMV and TMV. Molecules 15: 6713-6721.

5. Meena RK, Patni V, Arora DK (2008) Study on phenolics and their oxidative enzyme in Capsicum annuum L, infected with geminivirus. Asian J Exp Sci 22: 307-310.

6. Scalbert A (1991) Antimicrobial properties of taninna. Phytochemistry 30: 38753883.

7. Al-Beitawi NA, El-Ghousein SS, Nofal AH (2009) Replacing bacitracin methylene disalicylate by crushed Nigella sativa seeds in broiler rations and its effects on growth, blood constituents and immunity. Livest Sci 125: 304-307.

8. Mohamed EF (2011) Inhibition of broad bean mosaic virus (BBMV) using extracts of Nigella (Nigella sativa L.) and Zizyphus (Zizyphus spina-christi Mill.) plants. J Am Sci 7: 727-734

9. Li Y, Xu C, Zhang Q, Liu JY, Tan RX (2005) In vitro anti-Helicobacter pylori action of 30 Chinese herbal medicines used to treat ulcer diseases. J Ethnopharmacol 98: 329-333

10. Chaieb K, Hajlaoui H, Zmantar T, Kahla-Nakbi AB, Rouabhia M, et al. (2007) The chemical composition and biological activity of clove essential oil, Eugenia caryophyllata (Syzigium aromaticum L. Myrtaceae): A short review. Phytother Res 21: 501-506.

11. Fu Y, Zu Y, Chen L, Shi X, Wang Z, et al. (2007) Antimicrobial activity of clove and rosemary essential oils alone and in combination. Phytother Res 21: 989994.

12. Lee HS, Ahn YJ (1998) Growth-Inhibiting effects of Cinnamomum cassia barkderived materials on human intestinal bacteria. J Agric Food Chem 46: 8-12.

13. Inouye S, Takizawa T, Yamaguchi H (2001) Antibacterial activity of essentia oils and their major constituents against respiratory tract pathogens by gaseous contact. J Antimicrob Chemother 47: 565-573.

14. Stahl-Biskup E, Saez F (2002) Thyme. Taylor and Francis, London, UK.

15. O'Hara M, Kiefer D, Farrell K, Kemper K (1998) A review of 12 commonly used medicinal herbs. Arch Fam Med 7: 523-536.

16. Malu SP, Obochi GO, Tawo EN, Nyong BE (2009) Antibacterial activity and medicinal properties of ginger (Zingibre officinale). Global J Pure and Applied Science 15: 365-368.

17. Sebiomo A, Awofodu AD, Awosanya AO, Awotona FE, Ajayi AJ (2011) Comparative studies of antibacterial effect of some antibiotics and ginger (Zingibre officinale) on two pathogenic bacteria. J Microbiol Antimicrob 3: 1822.

18. Clark RK, Menory RC (1980) Environmental effects of peppermint (Mentha piperita). Aust J Plant Physiol 7: 685-692.

19. Diaz R, Quevedo-Sarmiento J, Ramos-Cormenzana A Cabo P, Cabo (1988) Phytochemical and antibacterial screening of some species of Spanish Lamiaceae. Fitoterapia 59: 330-333.

20. Walker JT, Melin JB (1996) Menthaxpiperita, Mentha spicata and effects of their essential oils on Meloidogyne in soil. J Nematol 28: 629-635.

21. Saeed S, Tariq P (2008) In vitro antibacterial activity of clove against Gram negative bacteria. Pakistan J Bot 40: 2157-2160.

22. Saeed S, Naim A, Tariq $P$ (2007) A study on prevalence of multi-drug-resistant Gram-negative bacteria. Int J Biol Biotech 4: 71-74

23. Abdel-Shafi S (2005) Biological studies on antiviral activities of some bacteria isolates Ph.D. Thesis, Dept of Bot Microbiol, Faculty of Science, Zag Univ, Egypt.

24. Clark MF, Adams AN (1977) Characteristics of the microplate method of enzyme-linked immunosorbent assay for the detection of plant viruses. J Gen Virol 34: 475-483.

25. Faccioli G, Capponi R (1983)An antiviral factor present in plants of Chenopodium amaranticolor locally infected by tobacco necrosis virus: 1 -Extraction, partia purification, biological and chemical properties. Phytopathol Z 106: 289-301.

26. Yarwood CE (1955) Mechanical transmission of apple mosaic virus. Hilgardia 23: $613-628$.

27. Campbell MM, Ellis BE (1992) Fungal elicitor-mediated responses in pine cell cultures: Cell wall-bound phenolics. Phytochemistry 31: 737-742.

28. Funk C, Brodelius PE (1990) Phenylpropanoid metabolism in suspension cultures of Vanilla planifolia Andr.: III. Conversion of 4-Methoxycinnamic Acids into 4-Hydroxybenzoic Acids. Plant Physiol 94: 102-108.

29. Julkunen-Tiitto R (1985) Phenolics constituents in the leaves of northern willows: Methods for the analysis of certain phenolics. J Agr Food Chem 33 213-217.

30. Kar M, Mishra D (1976) Catalase, peroxidase, and polyphenoloxidase activities during rice leaf senescence. Plant Physiol 57: 315-319.

31. Lowry OH, Rosebrough NJ, Farr AL, Randall RJ (1951) Citation Classics. J Bio Chem 193: 265.

32. SAS ${ }^{\circledR}$ (1996) User`s Guide: Statistics, Version 6. (12 ${ }^{\text {th }}$ Edn), SAS inst Inc, Cary, NC, USA.

33. Duncan DB (1955) Multiple ranges and multiple F. test. Biometric 11: 1-42.

34. Solanki R (2010) Some medicinal plants with antibacterial activity. Pharmacie Global (IJCP) 1: 1-4

35. Mahesh B, Satish S (2008) Antimicrobial activity of some important medicinal plant against plant and human pathogens. World Agric Sci 4: 839-843. 
Citation: Abdel-Shafi S (2013) Preliminary Studies on Antibacterial and Antiviral Activities of Five Medicinal Plants. J Plant Pathol Microb 4: 190 doi:10.4172/2157-7471.1000190

36. Sher A (2009) Antimicrobial activity of natural products from medicinal plants. Gomal J Med Sci 7: 72-78.

37. Tona L, Kambu K, Ngimbi N, Cimanga K, Vlietinck AJ (1998) Antiamoebic and phytochemical screening of some Congolese medicinal plants. J Ethnopharmacol 61: 57-65.

38. Ekweny UN, Elegalam NN (2005) Antibacterial activity of ginger (Zingiber officinale) Roscoe and garlic (Allium sativum L.) extracts on Escherichia coli and Salmonella typhyi. Int J Mol Med Adv Sci 1: 411-417.

39. Mashhadian NV, Rakhshandeh H (2005) Antibacterial and antifungal of Nigella sativa extracts against $S$. aureus, $P$. aeruginosa and $C$. albicans. Pak J Med Sci 21: 47-52.

40. Zuridah H, Fairuz ARM, Zakri AHZ, Rahim MNA (2008) In vitro antibacterial activity of Nigella sativa against Staphylococcus aureus, Klebsiella pneumoniae, Escherichia coli and Bacillus cereus. Asian J Plant Sci7: 331-333.

41. Mohamed $\mathrm{AH}$ (2008) In vitro selection of soybean callus for wilt disease resistance. Phd Thesis. Fac of Sci Zag Univ, Egypt.

42. Arfaoui A, Sifi B, Boudabous A, El-Hadrami I, Cherif M (2006) Effect of Rhizobium isolates on isoflavinoids contents in chickpea plants infected with Fusarium oxysporium f.sp. ciceris. Phytopathologica Mediterranian.

43. Saravanan T, Bhaskaran R, Muthusamy M (2004) Pseudomonas flurescens induced enzymological changes in banana roots against Fusarium wilt disease. Plant Pathol J 3: 72-80.

44. Mazid MA, Datta BK, Nahar N, Bashar SAMK, Bachar SC, et al. (2011) Phytochemical sudies on Polygonum barbatum (L.) Hara var. barbata (Polygonaceae). Rec Nat Prod 5: 143-146.

45. Ghosal TK, Dutta S, Senapati SK, Deb DC (2004) Role of phenol contents in legume seeds and its effect on the biology of Collosbrchus chinensis. Ann PI Protect Sci 12: 442-444.

46. Devanathan M, Ramaiah M, Sundar AR, Murugan M (2005) Changes of peroxidase and polyphenol oxidase in bunchy top nana virus infected and healthy cultivars of banana. Annals of Plant Physiology 19: 114-116.

47. Diwan H, Khan I, Ahmad A, Iqbal M (2010) Induction of phytochelatins and antioxidant defence system in Brassica juncea and Vigna radiate in response to chromium treatments. Plant Growth Regulation 61: 97-107.
48. Hernandez JA, Jimenez A, Mullineaux PM, Sevilla F (2000) Tolerance of pea (Pisum sativum L.) to long term salt stress is associated with induction of antioxidant defences. Plant Cell Environ 23: 853-862.

49. Panda SK, Khan MH (2009) Growth, oxidative damage and antioxidant responses in greengram (Vigna radiata L.) under short-term salinity stress and its recovery. J Agr Crop Sci 195: 442-454.

50. Montalbini P, Buonaurio R, Kumar NNU (1995) Peroxidase activity and isoperoxidase pattern in tobacco leaves infected with tobacco necrosis virus and other viruses inducing necrotic and non necrotic alterations. J Phytopathol143: 295-301.

51. Karakaya S, EI SN, Taş AA (2001) Antioxidant activity of some foods containing phenolic compounds. Int J Food Sci Nutr 52: 501-508.

52. Kofalvi SA, Nassuth A (1995) Influence of wheat streak mosaic virus infection on phenylpropanoid metabolism and the accumulation of phenolics and lignin in wheat. Physiol Mol Plant Pathol 47: 365-377.

53. Lam TB, liyama TK, Stone BA (1992) Changes in phenolic acids from internode walls of wheat and Phalaris during maturation. Phytochemistry 31: 2655-2658.

54. Cheema SS, Thiara SK, Kang SS (2003) Biochemical changes induced by soybean yellow mosaic virus in two soybean varieties. Plant-Disease Research, Ludhiana, India 18: 159-161.

55. Haque MN, Kundu AK, Shaifullah SMK (2005) Studies on the chemica composition and physiology of Zucchini yellow mosaic virus infected.

56. Muqit A, Akanda AM, Kader KA (2007) Biochemical alteration of cellular components of ash gourd due to infection of three different viruses.

57. Rao G, Ghosal M, Shukla K (1989) Comparative study of carbohydrate and protein content of Radish mosaic virus infected, inhibitor treated and healthy radish plants. Indian J Virol 5: 123-126.

58. Seden MEA, Abbas AE, Ahmed MH (2009) Effect of Origanum vulgare as a feed additive on growth performance, feed utilization and whole body composition of Nile tilapia (Oreochromis niloticus) fingerlings challenged with pathogenic Aeromonas hydrophila. J Agric Scix 34: 1683-1695.

59. Saeed S, Tariq P (2005) Antibacterial activities of Mentha piperita, Pisum sativum, Momordica charantia. Pak J Bot 37: 997-1001. 